\title{
Impact of Harvesting and Marketing Behavior of Citrus Growers on their Socio-Economic Development: A Case of District Sargodha
}

\author{
Nadeem Anwar', Muhammad Luqman ${ }^{2 *}$, Shaoib Nasir ${ }^{3}$, Moazzam Sabir ${ }^{1}$, Hafiz Bashir Ahmad ${ }^{4}$ and Sal- \\ eem Ashraf ${ }^{5}$
}

${ }^{1}$ Department of Agricultural Economics, College of Agriculture, University of Sargodha, Pakistan; ${ }^{2}$ Department of Agricultural Extension, College of Agriculture, University of Sargodha, Pakistan; ${ }^{3}$ Department of Agribusiness and Applied Economics, MNS University of Agriculture, Multan, Pakistan; ${ }^{4}$ Department of Forestry, College of Agriculture, University of Sargodha, Pakistan; ${ }^{5}$ In-Service Agriculture Training Institute, Rahim Yar Khan, Pakistan.

\begin{abstract}
Present research study was designed to investigate the impact of harvesting and marketing behavior of citrus growers on their socio-economic development. This research was conducted in district Sargodha, the hub of citrus production. The findings of the study indicate regarding harvesting behavior of the farmers that they do not harvest the fruit by their own. Only a small number of the citrus growers harvest the fruit by their own. Majority of the farmers were found to be unsatisfied about the role of intermediaries and termed these intermediaries as profit-making group indenting the share of farmers. The Harvesting behavior of the farmers is significantly affected by the area under citrus cultivation. The results also indicated that product marketing and harvesting behavior of citrus growers is positively associated with a unit increase in area under citrus cultivation. The analysis of Socio-economic characteristics of farmers sums up that the area under citrus cultivation is the most influencing characteristic that changes the marketing behavior of the farmers. Whereas the constraint analysis sums up that; large majority (83.6\%) of farmers reported high price of inputs as a key hurdle. Majority of the respondents revealed their concern on rising inflation in the country. They reported that the increase in cost of production negatively effects the profit earned especially by the small farmers. The results of inter-correlation analysis of variables, which are considered to be a constraining factor in citrus production confirms that most of the variables are interrelated and by resolving one, may lead to the resolution of other accompanying factors.

Received | May 03, 2021; Accepted | July 07, 2021; Published | August 24, 2021

*Correspondence | Muhammad Luqman, Department of Agricultural Extension, College of Agriculture, University of Sargodha, Pakistan; Email: muhammad.luqman@uos.edu.pk

Citation | Anwar, N., M. Luqman, S. Nasir, M. Sabir, H.B. Ahmad and S. Ashraf. 2021. Impact of harvesting and marketing behavior of citrus growers on their socio-economic development: A case of district Sargodha. Sarbad Journal of Agriculture, 37(4): 1167-1177.

DOI | https://dx.doi.org/10.17582/journal.sja/2021/37.4.1167.1177

Keywords | Citrus, Harvesting and marketing behaviour, Constraint analysis
\end{abstract}

\section{Introduction}

$\mathrm{P}$ akistan is ranked $15^{\text {th }}$ among citrus producing countries and is the sixth largest exporter of the citrus in the world (Naseer et al., 2019). The transition of ranks has been affected negatively due to quality deterioration and lack of standardization in the recent years. Due to increase in diseases, change in soil conditions and other different issues, economic losses of citrus are increasing every year. In Pakistan, citrus production was 2,458 thousand tons in 2005 while in 2019-20 citrus production has remained 2467 thousand tons. The export volume of citrus from Pakistan was 725 thousand tons with a value of 59,197 million rupees in 2019-20 to different countries (Ashraf et al., 2020). 
Punjab with its area of 182 thousand hectare and production of 2.3 million ton is the major supplier of the mandarin production in Pakistan (GoP, 2019). Kinnow is grown on $86 \%$ of area followed by Musambi which is grown on $10 \%$ of area, Friuter (4\%) and Red Blood on $1 \%$ of area. Approximately more than 95 $\%$ of the total Kinnow production owe to Pakistan (TDAP, 2021). Significant increase in Pakistan's agriculture output has not resulted in an improvement in the living standards of rural masses. Pakistani farmers face various problems in the supply of horticultural products because of their perishable nature and high hygienic standards for export. The global value chains are demanding and require advance technical knowledge and quality control. The marketing of citrus is more complex and riskier than other agricultural products as it requires special care and immediate harvest due to its ripening taste, water content, seasonality, and size (Usman et al., 2018). Citrus farmers of Pakistan lack in profit earning majorly because of the exploitative behavior of middleman and due to lack of interest and knowledge about appropriate technologies involved in growing fruit crops, suitable picking and packing, carriage requirements, marketing and export (Akhtar et al.,2018; Sharif et al.,2005; Usman et al., 2018). The problem is aggravated as Government failed to launch proper agriculture policy and to produce trained horticulture and extension workers. Daily studies have shown that small farmers in Pakistan are losing interest in citrus production due to low income and poor marketing system.

Many public and private institutions are keen in improving the financial status of the citrus farmers in the area. Nevertheless, absence of data and information, they are as yet not ready to meddle in this sub area. Limited multidimensional research studies are available regarding impact of harvesting and marketing behavior of citrus growers on their socio-economic development particularly in district Sargodha. With this rational the present research study was designed with following field/working objectives:

\section{Study objectives}

The study has following objectives:

1. To explore the harvesting and marketing behavior of the citrus farmers in the research area.

2. To find out the impact of socio-economics characteristics of farmers on harvesting and marketing behavior of the farmers.

3. To identify the value share of each intermediary in the percentage of the consumer price of different marketing channels.

4. To explore the major constraints faced by the citrus farmers in the production, harvesting and marketing of their produce.

\section{Matrials and Methods}

\section{Study area}

The study was conducted in district Sargodha which is one of the important districts of the Punjab province in terms of crop and livestock production. The surrounding districts of Sargodha are Jehlum, Khushab, Chaniot, Hafizabad and Mandi Bahaduddin. The district is administratively divided into 6 tehsils as shown in Figure 1.

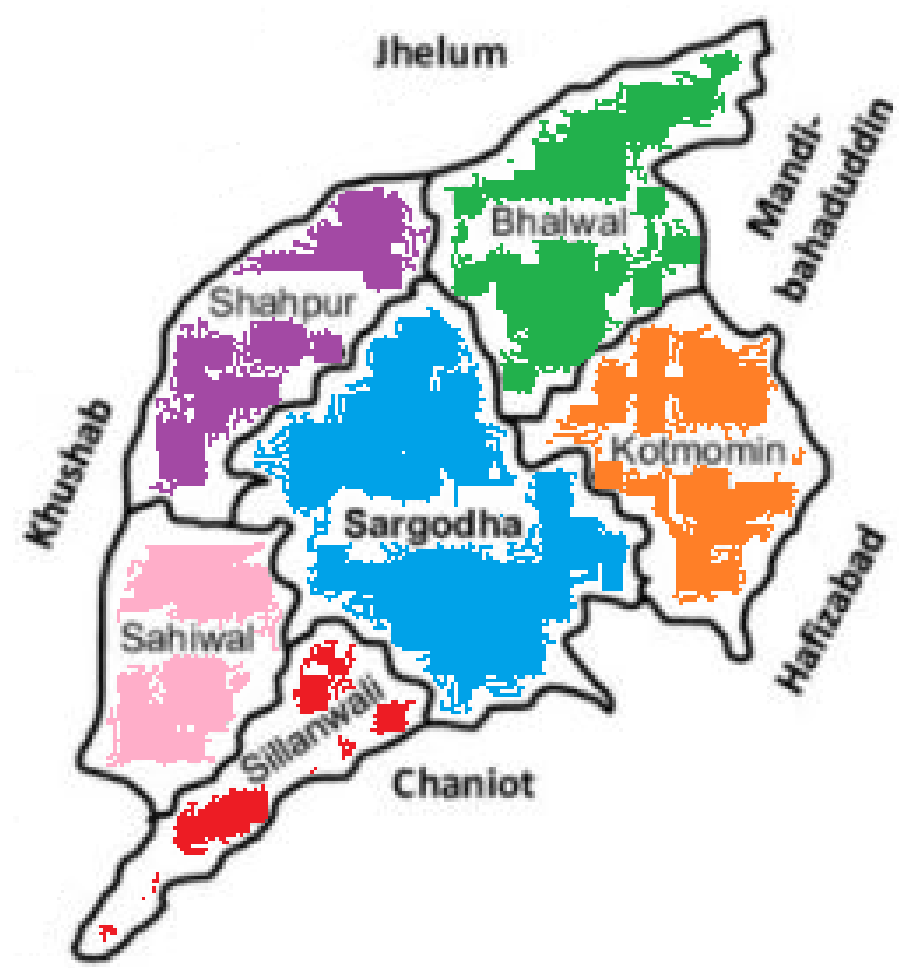

Figure 1: Map of administrative units (tehsils) of targeted research area (district Sargodha).

Sargodha district is well known and famous for quality Kinnow production nationally and internationally. According to an estimate about $23 \%$ of country's total citrus produces in district Sargodha (GoP, 2019). A number of kinnow processing units are located in this district.

\section{Sampling procedure}

Simple random sampling procedure was followed for the selection of respondents from all the six tehsils of district Sargodha. List of farmers growing citrus was prepared with the help of staff of Economics and 
Marketing wing (Sargodha district), Department of Agriculture, Government of the Punjab. From that list 45 farmers were randomly selected as the study subjects from each tehsil. Data were collected from 270 citrus growers. Data were also collected from citrus processors and for this purpose 15 citrus processors from each tehsil were also selected as the respondents of present study. Additionally, people involved in trading of citrus were also the part of current research and 14 citrus traders from each tehsil were interviewed. The rational behind collection of data from different stakeholders of citrus production, processing, marketing and export was to study the different marketing channels being used in Pakistan. These marketing channels were exclusively discussed by Jan (2012).

\section{Method of data collection}

Primary data were collected with the help of a semi-structured questionnaire. Both open ended and close ended questions were included in the questionnaire keeping in mind the objectives of the study. The questionnaire was pre-tested through a pilot survey of different tehsils of District Sargodha before final data collection. Data were collected by trained data collection team. Two days training session was conducted to train the enumerators. The purpose of the training was to guide enumerators about questionnaire response cramming and to enhance communication skills and techniques. Secondary data were also collected from different institutional \& authentic online sources. For this purpose, staff of chamber of trade and commerce, agriculture market committee, department of agriculture, export promotion bureau, agriculture enterprises, federal bureau of Statistics, Citrus Research Institute, Sargodha and Agricultural Statistics of Pakistan. Information was also collected by observations, group discussion, key informant survey and visit of fruits markets and processing units.

\section{Data analysis}

The data was coded and entered in the excel file and analyzed by using Statistical Package for Social Sciences (SPSS), Python and its relevant library was used to visually enhance the results of cointegration table along with Microsoft Excel software package. Descriptive and correlational statistics was used for the interpretation of collected data. To find out the relationship between socio-economic attributes of respondents (age, education, land ownership, land tenancy status, area under citrus cultivation and varieties of citrus being grown) and marketing behaviour of respondents (Table 1), correlation was used.

\section{Results and Discussion}

\section{Demographics of respondents}

Farmers' demographic information is theoretically described in the present section. The demographic variables; age in complete years, education level, size of land holdings, tenancy status of land, area under cultivation and cultivar under cultivation are elaborated graphically. The response of each determinant is described in the term of percentage.

\section{Age in complete year}

The age of citrus farmers in complete years is explicated in Figure 1. The farmers are categorized in three age groups as; less than equal to 35 years old as young age group, 36 to 50 years old as middle age group and above 50 years old as old age group. Figure 1 shows that 38.3 percent citrus farmers persist in young age group. It also describes that 48.3 percent citrus farmers belong to middle age group. It finally explicates that only 13.3 percent citrus farmers are older than 50 years and above. Figure 2 concludes that most of the citrus farmers belong to the middle age group. This indicates that middle age group of citrus growers is very common in the targeted research area. The similar results were also reported by Ashraf et al. (2015) while measuring the perceived effectiveness of information sources regarding improved citrus production practices in district Sargodha. According to them about half percent of respondents belong to middle age group.

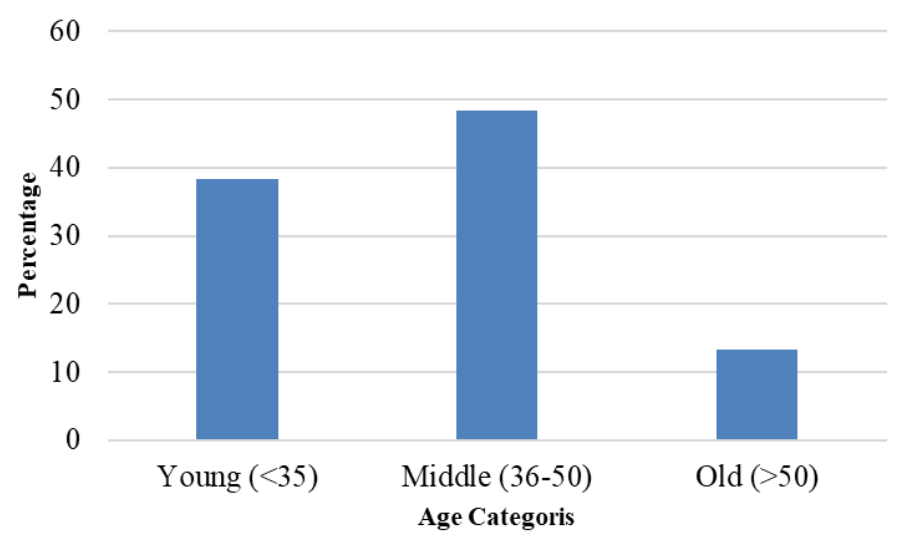

Figure 2: Age in complete year.

\section{Education Level}

The level of education of the citrus farmers is illustrated in the Figure 3. The citrus farmers are divided 
into the following education groups; illiterate, up to primary school education, from primary to middle school education, from middle to matriculation and above the matriculation level. Figure 3 shows that 24.3 per cent citrus farmers are illiterate and not even able to read and write. It shows that 18.66 per cent citrus farmers got education till the primary school level. It also shows that 30 per cent of citrus famers passed the primary to middle school education. It also explicates that 14.3 per cent citrus farmers get educated from middle to matriculation level of education. It finally describes that only 12.66 per cent of the citrus farmers passed the matriculation and the higher level of the education. The findings presented in the Figure 3 also shows that a large portion of citrus farmers contains on illiterates and also less educated farmers. Most of the citrus farmers persist in the primary to middle school education group. Similar results were also reported by Ashraf et al. (2020) while analyzing the intermediaries that influences the citrus supply chain in Pakistan.

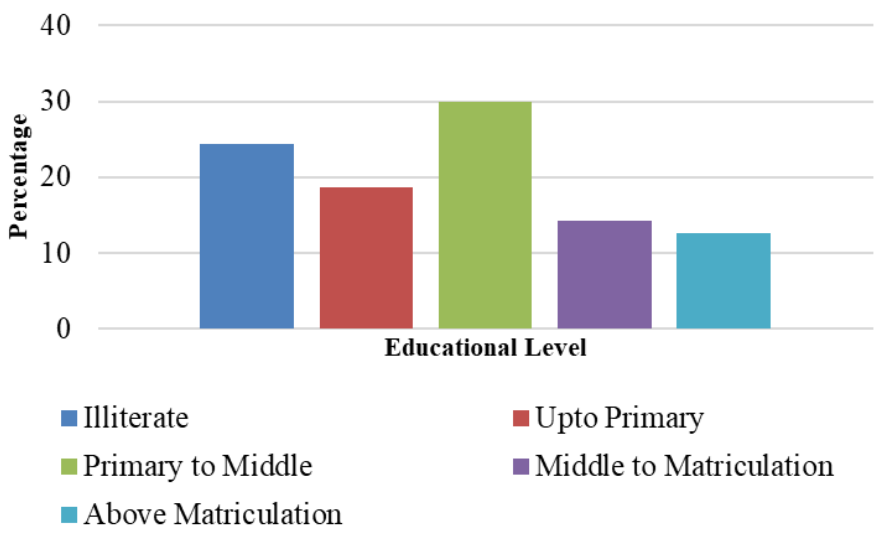

Figure 3: Education level.

\section{Size of land holdings}

The size of land holdings of citrus farmers is elaborated in the Figure 4. The collected information shows that 39.33 per cent of citrus farmers own the land holdings of less than 5 acres. It further explicates that 32.33 per cent citrus farmers possess the land holdings of 5 to 10 acres. It also indicates that 28.33 citrus farmers have the land holdings of more than 10 acres. Figure 4 supports the literature regarding smaller land holding of citrus farmers in the study area.

\section{Harvesting and marketing behavior}

The harvesting and marketing behavior of the citrus farmers is described in this section. The determinant of the harvesting behavior was selected as dummy variable, provided that the farmer either harvest the fruit the orchard at their own or not. The determinant of the marketing behavior of the farmers expresses the intention of the farmer regarding transaction of the citrus crop.

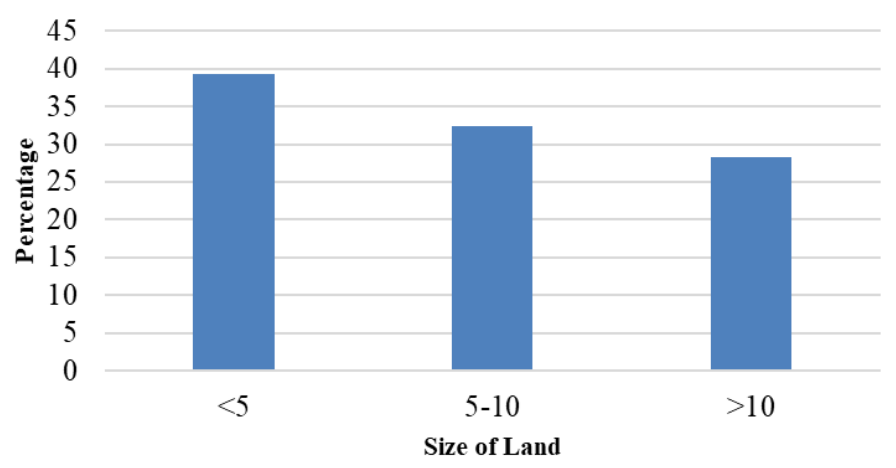

Figure 4: Size of land holdings.

\section{Harvesting behavior}

The harvesting behavior of the citrus farmers is explicated in the Figure 5. It shows that the 94 per cent of the citrus farmers do not harvest fruits from the orchard by their own. It also describes that 6 per cent of the citrus farmers' harvest the fruits from the orchard by their own. The reason behind might be the lack of appropriate skills and handling of harvested fruits (Khan et al., 2016). It can be concluded that most of the citrus farmers do not harvest the fruit by their own to avoid mismanagement during harvest of crop and post-harvest handling as well.

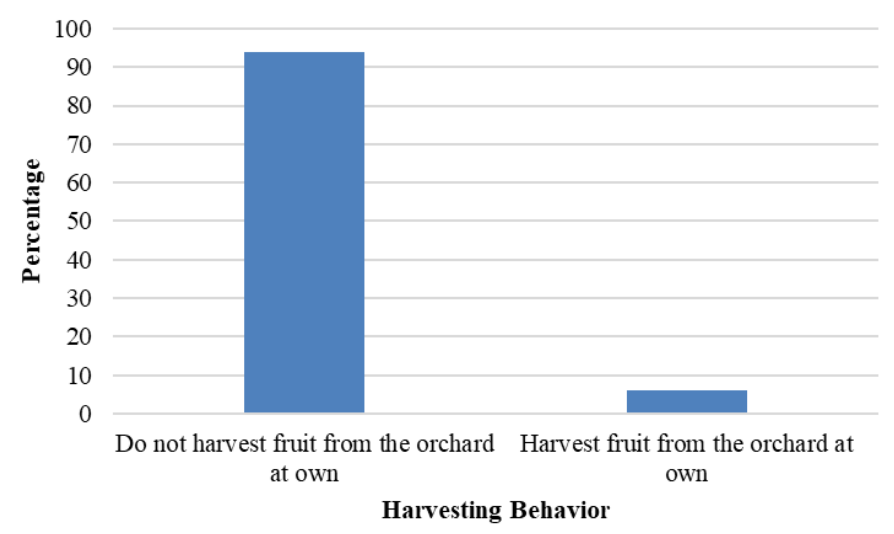

Figure 5: Harvesting behavior.

\section{Marketing behavior}

The marketing behavior of the citrus farmers is described in the Figure 6. It shows that 54 per cent of the citrus farmers sell the fruit to the citrus processing factories. It also elaborates the findings of the study that 31 per cent of the citrus farmers sell the produced fruit to the middleman. It further explicates that 15 per cent of the farmers sell the fruit to the friends and fellow farmers. Figure 6 concludes that 
most of the farmers sell the fruits to the processing factories.

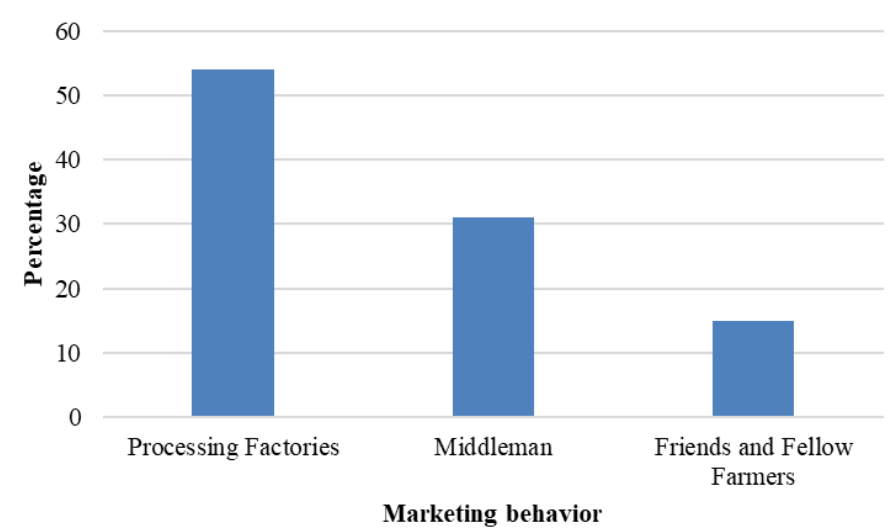

Figure 6: Marketing behavior.

From the above discussion it is obvious that 94 per cent of citrus farmers didn't harvest their orchid by their own and sell their pre-harvest produce to processing units and marketing agents. Buyers whether they are processing units or marketing agents are responsible for the harvesting once the produce is sold. For example, processing units opt for mechanical harvesting as they have abundant financial resources and they have to follow export regulations. Only 6\% farmers harvest their orchards by themselves by hiring local labor. It expresses that processing units, middleman and fellow farmers are the most prominent stakeholders as far as harvesting of citrus is concerned. Slamet et al. (2017) and Ullah et al. (2017) have endorsed that commission agents, middleman and processing units are leading intermediaries in the citrus marketing system. Similarly, $56 \%$ of farmers sell their pre-harvest produce to processing units, $31 \%$ to middleman and $15 \%$ to friends and fellow farmers. Farmers described that the whole region is rich in citrus cultivation and processing units have an organized system to buy pre-harvest fruit for export. Farmers showed their satisfaction about the price of citrus. Majority of the farmers were found to be unsatisfied about the role of intermediaries and termed these intermediaries as profit-making group indenting the share of farmers. It was also found that $15 \%$ of the farmers sell their pre-harvest fruits to fellows and relatives. More or less similar findings were also reported by Ashraf et al. (2020) regarding harvesting as well as marketing behavior of citrus growers. They concluded that a large majority of the respondents reported that they didn't harvest their citrus orchards by their own. In connection with the findings of present study U1lah et al. (2017) also recommended that commission agents/middleman and kinnow processing factories are major mediators in the citrus marketing system in Pakistan. As per discussion with different stakeholders of citrus supply chain specifically in district Sargodha and general in the whole country following are the intermediaries. The flow chart of these intermediaries is well illustrated in Figure 7.

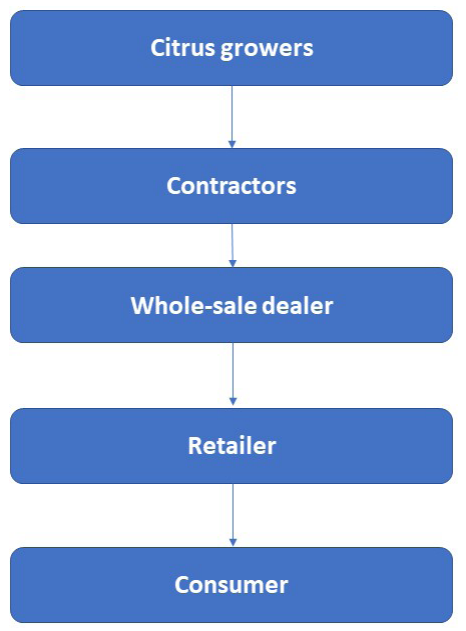

Figure 7: Socio-economic impact

Table 1 shows the socio-economic impact of citrus farmer's characteristics on the harvesting and marketing behavior of the farmers. It explicates the impact of; age, education, land ownership, tenancy status, areas under cultivation and varieties under cultivation on the harvesting and marketing behavior of the farmers. It shows that the demographic characteristics of the farmers positively affect their harvesting and marketing behavior (Bonales-Valencia et al., 2019). (Ashraf et al.,2015; Franken et al., 2014; Higuchi et al., 2012) have found that farmer's marketing choices are determined by their socio-economic characteristics. The market participation depends upon socio-economic characteristics such as gender of the household head, age of the farmers, tenancy status, vocational training, educational level and irrigated land (Abdullah et al., 2019; Dessie et al., 2017; Greiner et al., 2009). Outcomes of the study showed that relationship of grower's age, landholding size, tenancy status and varieties under cultivation was non-significant with harvesting behavior of citrus growers. Educational level was highly significant $(\mathrm{P}<0.01)$ with harvesting behavior. This infers that harvesting behavior of farmers tend to be more positive with the increase in education. Being educated, farmer's judgement is more optimistic to decide the appropriate method of harvesting to decrease losses and ensuring quality. 
Table 1: Determinants of socio-economic Impact.

$\begin{array}{lllll}\text { Socio-Economic Attributes } & \text { Harvesting Behavior } & \text { Processing Factory } & \text { Middle man } & \text { Friends/neighbors } \\ \text { Age } & 0.13 & 0.27 & 0.159 & 0.044^{*} \\ \text { Education } & 0.008^{* *} & 0.094^{*} & 0.371 & 0.229 \\ \text { Land ownership } & 0.801 & 0.001^{* *} & 0.103 & 0.817 \\ \text { Tenancy status } & 0.69 & 0.112 & 0.877 & 0.104 \\ \text { Area under citrus cultivation } & 0.089^{*} & 0.081^{*} & 0.017^{*} & 0.014^{*} \\ \text { Varieties cultivated } & 0.991 & 0.059^{*} & 0.458 & 0.994\end{array}$

${ }^{*} P<0.05{ }^{* *} P<0.01$

Table 1 shows the positive but non-significant relationship between age of farmers and their harvesting behavior. It shows that as the age of farmers increased by one unit their harvesting behavior change by 0.13 units. It also shows that one unit increase in the age of farmers change the selling behavior of the farmers by 0.27 units to sell the fruit to the processing factory. It concludes that one unit increase in the age of farmers change the selling behavior of the farmer by 0.159 units to sell the fruit to the middleman. A one unit increase in the age of farmers change the selling behavior of the farmers by 0.044 units to sell the fruit to the friends and fellow farmers was also observed.

Table 1 shows the positive relationship between education of farmers and their harvesting behavior. It shows that as the education of farmers increased by one unit their harvesting behavior changes by 0.008 units. A positive change of 0.094 units to sell the fruit to the processing factory was observed by a unit increase in the education of farmers change the selling behavior of the farmers by 0.094 . Whereas one unit increase in the education of farmers changes the selling behavior of the farmer by 0.371 units to sell the fruit to the middleman. A change in the selling behavior of the farmers by 0.229 units to sell the fruit to the friends and fellow farmers was observed by increase in one unit of farmers education.

Table 1 shows the positive relationship between land possessed by farmers and their harvesting behavior. It shows that as the land possessed by farmers increased by one unit their harvesting behavior change by 0.801 units. It also shows that one unit increase in the land possessed by farmers change the selling behavior of the farmers by 0.001 units to sell the fruit to the processing factory and changes by 0.0103 and 0.817 units to sell the fruit to the middle man to the friends and fellow farmers respectively.
Table 1 also illustrates the positive relationship between tenancy status of farmers and their harvesting behavior. It shows that as the tenancy status of land changes from tenancy to ownership the harvesting behavior of farmer changes by 0.69 units. It also shows that as the tenancy status of land change from tenancy to ownership the selling behavior of farmer change by 0.112 and 0.877 units to sell the fruit to the middleman and to the processors respectively. It further shows that as the tenancy status of land change from tenancy to ownership the selling behavior of farmer changes by 0.104 units to sell the fruit to the friends and fellow farmers.

The positive relationship between area under cultivation of farmers and their harvesting behavior is also exhibited in the table 1.It shows that as the area under cultivation of farmers increases by one unit their harvesting behavior change by 0.089 units. It also shows that one unit increase in the area under cultivation changes the selling behavior of the farmers by 0.081 units to sell the fruit to the processing factory. It further shows that one unit increase in the area under cultivation changes the selling behavior of the farmer by 0.017 units to sell the fruit to the middleman. It further explicates that one unit increase in the area under cultivation changes the selling behavior of the farmers by 0.014 units to sell the fruit to the friends and fellow farmers.

Table 1 shows the positive relationship between variety under cultivation and harvesting behavior of farmers. It shows that when farmers grow varieties other than Kinnow their harvesting behavior changes by 0.991 units. It also shows that when farmers cultivate other than Kinnow their selling behavior changes by 0.059 units to sell the fruit to the processing factory. It further shows that when farmers cultivate other than Kinnow their selling behavior change by 0.458 units to sell the fruit to the middleman. It fur- 
ther explicates that when farmers cultivate other than Kinnow their selling behavior change by 0.994 units to sell the fruit to the friends and fellow farmers. The Harvesting behavior of the farmers is significantly affected by the area under citrus cultivation. Results indicate that behavior of farmers about product marketing changes positively with a unit increase in an area under citrus cultivation.

Marketing behavior was non-significantly related with the age and tenancy parameters. The educational status had significant association with marketing to processing units $(\mathrm{P}<0.05)$ followed by the area under citrus cultivation and varieties grown having significant relationship $(\mathrm{P}<0.05)$. Results indicates that farmers are in better position to sell their pre-harvest produce with a positive change in characteristics like, higher qualification, large landholdings, area under citrus cultivation and type of varieties being cultivated. It is easy and cost effective for farmers to sell their produce to processing units.

Marketing of produce to middleman is significantly related with the area under citrus cultivation $(\mathrm{P}<0.05)$. It can be assumed that small farmers prefer middleman to sell their produce in order to reduce cost and increase their profit. Selling produce to fellows and neighbors is significantly related with age and area under citrus cultivation $(\mathrm{P}<0.05)$. Farmers will be more concerned and focused to choose effective marketing options as the area and production increases. So, the analysis of socio-economic characteristics of farmers sums up that the area under citrus cultivation is the most influencing characteristic that changes the marketing behavior of the farmers. In relation to these findings, Higuchi et al. (2012) also reported socio-economic attributes as an major interpreter behind choice of marketing channel by the farmers. The same was also confirmed by Ashraf et al. (2020) and Abdullah et al. (2019). They concluded that gender, age, tenancy status, educational/ training level possessed by the farmers, and area under cultivation were the major determinants behind selection of market channel by the farmers.

\section{Marketing margin and value share of stakeholders}

The following local marketing channels were identified during a group discussion with different stakeholders i.e. producers, traders and processors.

1. Producer-pre-harvest contractor- retailer- con sumer.

2. Producer-commission agent-retailer-consumer.

3. Producer-pre-harvest contractor-commission agent- retailer-consumer.

4. Producer-processor- retailer(abroad)-consumer.

Table 2 elaborates the value share of intermediaries involved in the above marketing channels. Table 2 shows the average total marketing margin and shares in percentage of the consumer price of each intermediary involved in different marketing channels. Share of producer in consumer price varies from 52.22 to 65.88 percent. The average total marketing share in consumer price in different marketing channels varies from 34.12 to 47.78 percent. Share of pre-harvest contractor varies from 25.23 to 25.23 of consumer price and highest among all intermediaries. The average value share of processors is 32.44 percent of consumer price and the second highest. Retailers get 14.27 to 18.33 of consumer price whereas commission agents get 7.01 to 15.79 percent of consumer price in different marketing channels. It is obvious from the above discussion that large portion $(42.95 \%)$ of consumer price in the citrus value chain is engulfed by intermediaries while farmer gets only 57.05 percent.

\section{Constraint analysis}

The Figure 8 demonstrates the limitation of citrus producer as reported in farmer survey. A total sample of 270 has been analyzed for investigating the farmers` limitations. From the total sample size 83.6 percent farmers reported high price of inputs as a key hurdle. Responder exposed distress on rising inflation in the country as the increased in production cost minimize the small farmer profit. Being a small farmer is also a main hurdle a huge majority of 83 $\%$ respondents report this issue. Majority of people in Pakistan involve in agriculture are small farmers and living under the stress of debt provided by the middleman for assistance. Ansari et al. (2018) also reported the same issue and conclude credit cycle is driven by the middleman in rural areas. About $75.7 \%$ of respondents were unhappy with the monopoly of middleman. Respondents expose the role of middleman but due to financial issues farmers are bound to sell their product through traditional market mechanism e.g., middleman, commission agents or mafia. Naseer et al. (2019) argue that the traditional marketing channels did not affect the profit margin of farmers. Although, numerous recent studies like Ansari et al. (2018) had reported that intermediaries 
Table 2: Average percentage value share in consumer price.

\begin{tabular}{lllllll}
$\begin{array}{l}\text { Marketing Chan- } \\
\text { nels }\end{array}$ & $\begin{array}{l}\text { Total Marketing } \\
\text { Margin }\end{array}$ & $\begin{array}{l}\text { Pre-Harvest } \\
\text { Contractor }\end{array}$ & Processor & $\begin{array}{l}\text { Commission } \\
\text { Agent }\end{array}$ & Retailer & Producer \\
\hline 1 & 43.39 & 27.13 & - & 16.26 & 56.61 \\
\hline 2 & 34.12 & - & 15.79 & 7.01 & 14.33 & 65.88 \\
3 & 46.51 & 25.23 & & 53.49 & 52.22 \\
4 & 47.78 & - & 32.44 & - & 57.34 & 57.05
\end{tabular}

(middleman and retailer) have a key role in supply chain and never be ignored. However, Sharif et al. (2005) reported the similar findings that $89.6 \%$ of the farmers sell their orchard before the harvest to middleman and contractors. Siddique and Garnevska (2018) investigated the same problem while few of them sold their product directly to foreign and local market. Many benefits were high-jacked by middleman.

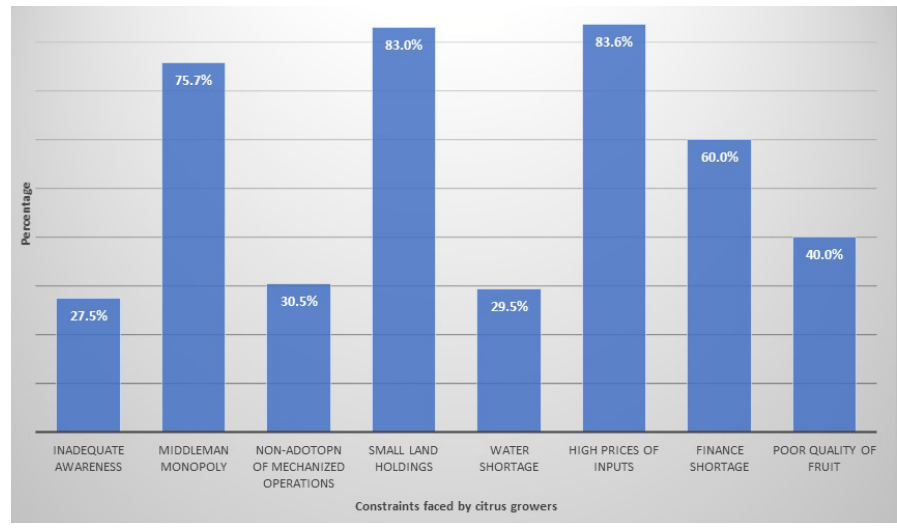

Figure 8: Constraint analysis.

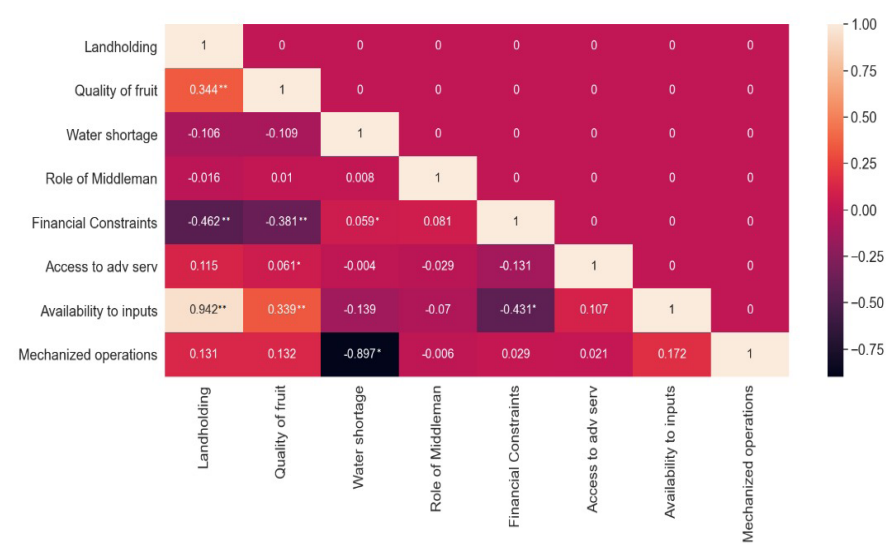

Figure 9: Correlation analysis.

${ }^{*} P<0.05$; ${ }^{* *} P<0.01$; Source: Authors compilations from data collection.

Usman et al. (2018) reviewed that dominated role of middleman cuts farmer's profits in many ways. Middleman provides false and misleading information (Khushk et al., 2006) to the farmers regarding price of the product and false information was revolved in the market by his team which minimize the farmer profit margins. Eventually, availability of solid market infrastructure (Fredriksson et al., 2017) is needed to increase the revenue of the farmer.

\section{Intercorrelation of variables}

Illustration of the correlation matrix was generated using heatmap function available in the numpy, seaborn and matplotlib libraries of Python programming. The gradient of color in the Figure 9 shows the intensity of correlation among the plotted variables (Lemenkova, 2019). The solid color exhibit a stronger relationship among variable and steric marks express the level of significance as per $\mathrm{P}$ values. The findings exhibit strong and negative correlation of financial constraint with land holding and quality of fruit whereas the correlation with water was found to be positive. The relation of landholding and access to advisory services was found positive and significantly affecting the fruit quality. The landholding size was positively correlated with the availability of inputs which related to the market-oriented disparities for small farmers. Figure 9 also shows that non-adoption of mechanized operation is significantly related with water shortage (0.897). it means that water shortage can be minimized by adopting better and mechanized irrigation techniques i.e., drip irrigation etc. The results of intercorrelation analysis of variables which are consider to be a constraining factor in citrus production confirms that most of the variable are interrelated and by resolving one, another can be lessened by itself.

\section{Conclusions and Recommendations}

It was concluded from the results that majority of the respondents belong to middle age category (36-50 
years). Educational status of respondents is not satisfactory as majority of the respondents had only 5 years (primary level education) of schooling. This indicates that in the research area, majority of the farmers didn't possess higher education, which is one of the major constraints towards adoption of modern citrus farming practices. These findings are in accordance with the national literacy rate as educational level is low in rural localities compared to urban ones. This is very unfortunate that no respondent from the area had university level education (graduation or master). This also indicates that young generation is not too much involved in farming activities. They have least interest in earning income through agriculture. Results also indicate that small size of landholding is very common in the targeted research areas as majority of the respondents possessed less than 5 acres of agricultural land. This is also one of the reasons behind low-income level of majority of the respondents in the area. In majority of the developing countries like Pakistan small size of farmers are in majority in all the four provinces. The results regarding harvesting behavior of citrus growers indicate that most of the citrus farmers do not harvest the fruit by their own to avoid mismanagement during harvest of crop and post-harvest handling as well. Most of the farmers sell the fruits to the processing factories. An overwhelming majority of citrus growers didn't harvest their orchid by their own and sell their pre-harvest produce to processing units and marketing agents. Buyers whether they are processing units or marketing agents are responsible for the harvesting once the produce is sold. Majority of the citrus growers are very much satisfied regarding price of the citrus in national and international markets. Determinants of socio-economic impact (harvesting behavior, processing factory, middlemen and friends/neighbors) indicate that the area under citrus cultivation is the most influencing characteristic that changes the marketing behavior of the farmers. It can also be concluded from the findings that large portion $(42.95 \%)$ of consumer price in the citrus value chain is engulfed by intermediaries while farmer gets only $57.05 \%$. The results of intercorrelation analysis of variables which are consider to be a constraining factor in citrus production confirms that most of the variable are interrelated and by resolving one, another can be lessened by itself. Development of organized marketing structure to alleviate intermediary's monopoly which increases the economic share of citrus farmers is recommended. This study also urges authorities to control input prices and develop a mecha- nism of corporate farming for small farmers to retain market power and get benefits of economies of scale.

\section{Acknowledgements}

This manuscript is the part of research project titled "Value Chains of Citrus and Socio-Economic Development: A Case of District Sargodha" funded by Office of Research, Innovation and commercialization (ORIC), University of Sargodha, Sargodha. The authors highly acknowledged the financial support provided by University of Sargodha.

\section{Novelty Statement}

Harvesting and Marketing behaviour of citrus growers is very much complex especially in deter-mining marketing channels of fruits and vegetables in the scenario of developing countries including Pakistan. Present research is unique in the context of identifying impact of socio-economic attrib-utes of citrus growers on their Harvesting and Marketing behaviour.

\section{Author's Contribution}

Nadeem Anwar: Conceived the main theme of the research and supervised the whole research.

Muhammad Luqman: Prepared initial draft of manu-script.

Shoaib Nasir: Performed data analysis.

Moazzam Sabir: Prepared data collection instruments and helped in data collection.

Hazfiz Bashir Ahmad: Collected relevant review of literature.

Saleem Ashraf: Proof read and finalized the manuscript.

\section{Conflict of interest}

The authors declare no conflict of interest.

\section{References}

Abdullah, Rabbi, F., Ahamad, R., Ali, S., Chandio, A.A., Ahmad, W., Ilyas, A. and Din, I.U. 2019. Determinants of commercialization and its impact on the welfare of smallholder rice farmers by using Heckman's two-stage approach. J. Saudi Soc. Agric. Sci. 18(2): 224-233. https://doi. org/10.1016/j.jssas.2017.06.001 
Akhtar, S., LI, G. cheng, Ullah, R., Nazir, A., Iqbal, M. A., Raza, M. H., Iqbal, N. and Faisal, M. 2018. Factors influencing hybrid maize farmers' risk attitudes and their perceptions in Punjab Province, Pakistan. J. Integr. Agric. 17(6): 1454-1462. https://doi.org/10.1016/S20953119(17)61796-9

Ansari, N., R. Mehmood and H. Gazdar. 2018. Analysing Pakistan's modern dairy value-chain innovation, LANSA working paper series, No. 29.

Ashraf, S., Khan, G. A., Ali, S. and Iftikhar, M. 2015. Socio-economic determinants of the awareness and adoption of citrus production practices in Pakistan. In Ciência Rural, Santa Maria. 45 (9): 1701-1706. https://doi.org/10.1590/0103$8478 \mathrm{cr} 20131227$

Ashraf, S., Khan, G. A., Ali, S., Ahmed, S. and Iftikhar, M. 2015. Percieved effectiveness of information sources regarding improved practices among citrus growers in Punjab, Pakistan. Pak. J. Agric. Sci. 52(2): 1-6.

Ashraf, S., Saqib, R., Hassan, Z. Y., Luqman, M. and Rehman, A. 2020. Analysis of intermediaries' influence in citrus supply chain in Pakistan. Sarhad J. Agric. 36(1): 210-216. https://doi. org/10.17582/journal.sja/2020/36.1.210.216

Bonales-Valencia, J., Ortiz-Paniagua, C. and Gaytán-Cortes, J. 2019. Innovation in Citrus Value Chain Competitiveness. Competition Forum. 17(1): 114.

Dessie, M., Woldeamanuel, T. and Mekonnen, G. 2017. Market Chain Analysis of Red Pepper: The Case of Abeshge District, Guragie Zone, South Ethiopia Mekdes. Am.J. Environ. Resour. Econ. 2(2): 62-72. https://doi.org/10.19080/ IJESNR.2017.02.555590

Franken, J. R. V., Pennings, J. M. E. and Garcia, P. 2014. Measuring the effect of risk attitude on marketing behavior. Agric. Econ. (United Kingdom). 45(5): 525-535. https://doi.org/10.1111/ agec. 12104

Fredriksson, L., A. Bailey, S. Davidova, M. Gorton and D. Traikova. 2017. The commercialisation of subsistence farms: Evidence from the new member states of the EU. Land Use Policy. 60: 37-47. https://doi.org/10.1016/j.landusepol.2016.10.009

GoP. 2019. Economic Survey of Pakistan. Economic Advisor's Wing, Government of Pakistan, Islamabad.
Greiner, R., Patterson, L. and Miller, O. 2009. Motivations, risk perceptions and adoption of conservation practices by farmers. Agric. Syst. 99: 86-104. https://doi.org/10.1016/j. agsy.2008.10.003

Higuchi, A., Moritaka, M. and Fukuda, S. 2012. The Impact of Socio-Economic Characteristics on Coffee Farmers' Marketing Channel Choice: Evidence from Villa Rica, Peru. Sustainable Agric. Res. 1(1): 13-18. https://doi. org/10.5539/sar.v1n1p13

Jan, A. 2012. Participation in farm markets in rural North-West Pakistan: A regression analysis. Pak. J. Commerce Soc. Sci. 6(2): 348-356.

Khan, F. U., Nowshad, K. and Fouzia, A. 2016. Farmers perception about yield losses of kinnow (Citrus reticulate) during its harvesting and post harvesting operations: a case study of tehsil Sargodha, Pakistan. J. Rural Dev. Agric. 1(1): 12-19. http://jrda.aiou.edu.pk/ojs/files/ journals/1/articles/10/public/10-54-1-PB.pdf

Khushk, A.M., A.S.L.A.M. Memon and M.I. Lashari. 2006. Marketing system of selected fruits in Pakistan. Bangladesh J. Agric. Res. 31(1): 39-68.

Lemenkova, P. 2019. Computing and Ploting correlograms by Python and $\mathrm{R}$ libraries for correlation analysis of the environmental data in $\mathrm{Ma}-$ rine Geomorphology. 2019(3): 1-16.

Naseer, M. A. ur R., Ashfaq, M., Hassan, S., Abbas, A., Razzaq, A., Mehdi, M., Ariyawardana, A. and Anwar, M. 2019. Critical issues at the upstream level in sustainable supply chain management of agri-food industries: Evidence from Pakistan's citrus industry. Sustainability. 11: 1-19. https://doi.org/10.3390/su11051326

Sharif, M., Farooq, U. and Malik, W. 2005. Citrus marketing in Punjab: Constraints and potential for improvement. Pak. Dev. Rev. 44(4 PART II): 673-693. https://doi.org/10.30541/ v44i4IIpp.673-694

Siddique, M.I. and E. Garnevska. 2018. Citrus value chain (s): A survey of Pakistan citrus industry. Agric. Value Chain. pp. 37. https://doi. org/10.5772/intechopen.70161

Slamet, A.S., Nakayasu, A. and Ichikawa, M. 2017. Small-scale vegetable farmers' participation in modern retail market channels in indonesia: The determinants of and effects on their income. Agriculture (Switzerland). 7(2). https:// doi.org/10.3390/agriculture7020011 
TDAP. 2021. Trade Statistics. Trade Development Authority of Pakistan. https://tdap.gov.pk/ trade-statistics/

Ullah, R., Safi, Q. S., Ali, G. and Ullah, I. 2017. Who gets what? Citrus marketing in Bunir District of Pakistan. Sarhad J. Agric. 33(3). 474-479. https://doi.org/10.17582/journal. sja/2017/33.3.474.479

Usman, M., Ashraf, I., Chaudhary, K.M. and Talib, U. 2018. Factors impeding citrus supply chain in Central Punjab, Pakistan. Int. J. Agric. Ext. 6(1): 01-05. https://doi.org/10.33687/ ijae.006.01.2301 